\title{
18. An Impecunious Election: The significance of fiscal and economic issues
}

\begin{abstract}
John Wanna
This election will be about who the Australian people best trust to lead them through the difficult new economic challenges that now lie ahead.-PM Kevin Rudd, August 2013.

This election is not just about economic management but economic management is the core issue because everything else-national security, border security, the delivery of better schools and hospitals, and the successful implementation of the National Disability Insurance Scheme-needs a strong economy to be sustainable.-Opposition Leader Tony Abbott, September 2013. ${ }^{1}$
\end{abstract}

Fiscal and economic policy loomed large as a policy contest in the 2013 election, but as an issue or set of issues it failed to capture the public mood or spark much overwhelming interest. ${ }^{2}$ Economic issues were more latent than front and centre, when some commentators felt that 'the economy should have been the cornerstone of the whole campaign' (see Harmon 2013). Indeed, the AES survey conducted immediately after the election found, unsurprisingly, that the management of the economy was rated by 94.5 per cent of respondents as very important and 81.4 per cent similarly thought taxation issues were important, but these attitudes did not shape the campaign strategies markedly (Bean et al. 2014: 79, 82). ${ }^{3}$ Worries of an impending economic recession were pronounced; escalating job losses occurring in the manufacturing and service sectors and in the public sector, investment trending downward, the mining boom coming off the boil, and fragilities in the retail sector, all added to the sense of nervousness and uncertainty. In addition, the Government's fiscal/budget difficulties and especially the depressed state of revenue returns kept the attention on the Government's performance with respect to economic management. Other

\footnotetext{
1 Rudd and Abbott quotes taken, respectively, from Abbott and Rudd 2013 and Abbott 2013.

2 Previous Australian election studies have rarely included separate chapters on the economy, business or fiscal policies; the exceptions in recent years are the collections produced for the 2007 and 2010 elections (see references in the Preface). Overseas electoral studies also rarely include chapters on the salience of economic issues in campaigns.

3 Moreover, some 27.5 per cent of respondents stated that the management of the economy was the most important issue during the campaign (the highest proportion) and a further 13.9 per cent claimed it was the second most important issue (again the highest combined salience) (see Bean et al. 2014: 86).
} 
'failings' brought on by the Government itself, such as its flawed and inflated estimates of economic growth forecasts, its overly optimistic projections of revenue receipts, and total lack of credibility in its sanguine budget projections of an imminent surplus, only magnified the impression the Government did not really know what it was doing.

Plausible explanations of why the economy was not more prominent as an electoral issue may include the fact that the Australian economy was comparatively not in a bad condition - inflation (+/-2 per cent) and unemployment (around 5.7 per cent) were relatively low, economic growth was positive (2.5 per cent), and the mining boom (commodity markets) had insulated the economy by maintaining export levels and sustained growth in the states of Western Australia and Queensland. Real incomes were rising by 3 pecent per annum. Yet, household cost of living pressures were mounting both in real terms (household utility bills) and as an electoral issue (living affordability); and there were regular media accounts of the increased incidence of poverty and welfare/food handouts. The structural budgetary problem was not something Labor was likely to canvass widely in the campaign, and the Coalition had to be very selective in its attacks because going too hard on this issue would raise fears of the necessary cuts the conservatives would have to make to return to surplus. To keep the issue alive but contained the Coalition proclaimed that Australia faced a real 'budget emergency' and mounting debt levels.

The other important factor about fiscal management was that, because economic activity was relatively flat, there was no real prospect of new money for policy announcements in the campaign or for the foreseeable future. Hence, an impecunious election was fought with virtually no vote buying to leaven the tedium of campaign negativity. The election was fought in a Micawberlike trance with both sides eschewing major spending commitments - only the Greens who were unlikely to be called upon to implement any announcements made extravagant commitments.

By the end of the election campaign the Coalition had made total promises amounting to $\$ 33.4$ billion but offset by cuts of $\$ 42$ billion, which over the four-year forward estimates saved the budget some $\$ 8$ billion. The Coalition committed to spending on new roads ( $\$ 5.4$ billion), a paid parental leave scheme ( $\$ 3.3$ billion), direct action on climate change ( $\$ 2$ billion), and restoring the fringe benefits tax (FBT) concession for company cars ( $\$ 1.8$ billion). It also had to offset the abolition of the carbon and mining taxes ( $\$ 9.7$ billion) and a cut in company tax rates ( $\$ 4.9$ billion). The Coalition announced savings (cuts) to the public service, the school kids bonus, foreign aid, low income super contributions, regional infrastructure, and the refugee intake (and reduced spending by 'stopping the boats') as well as a new levy on companies to pay for 
the parental leave scheme. Labor by contrast promised a paltry $\$ 0.5$ billion for better before and afterschool care, and its commitments amounted to a budget neutral stance.

\section{The primacy of economic policy and the disappearing surplus}

Economic and fiscal policies had been at the very forefront of the Labor Government's agenda since the early onset of the global financial crisis (GFC) in 2008. Given the severe financial shock hit the Government almost immediately after it assumed office in its first term, economic concerns were a perennial priority for Labor. It implemented a series of five stimulus packages over 200809, introduced an expansionary budget in May 2009, and then constantly wrestled with the difficulties of 'fiscal consolidation' with every budget from 2010-11 through to 2013-14 - arguably presiding over a deterioration in public finances. The Government took some courageous fiscal measures in its first term that helped prevent Australia from suffering the magnitude of economic woes that afflicted the United States and most of Europe, but difficulties in rebalancing the budget gradually began to hurt the Government's reputation and standing with business.

Treasurer Wayne Swan had pledged to deliver a surplus (absolutely guaranteed, 'come hell or high water') by the end of June 2013. His bravado was pure bluff and exaggeration. When it became impossible to pretend that a surplus would eventuate by that date, Swan quietly announced just before the Christmas break that the surplus commitment would be jettisoned, initially postponing the surplus another year to 2014 before admitting it would not be achieved until 2016-17. Many commentators were either fatalistically resigned to the likelihood of yet another deficit, or were relatively positive about the news because they feared any further contractionary measures would tip Australia into a recession. By 2013 the deficit was around \$40 billion for the year, and, counting the 2013-14 budget, Swan had delivered six consecutive deficit final budget outcomes, amounting to over $\$ 250$ billion in total. On 1 August 2013, after the return of Rudd to the leadership, Chris Bowen, Labor's new treasurer, had to introduce a mini budget and a new budget update (increasing the deficit projections to $\$ 58.8$ billion over three years), with various 'annoying' tax increases mooted ( $\$ 5$ billion extra in tobacco excise, increases in the FBT, a tax on bank deposits, higher visa charges, and a higher efficiency dividend).

Treasury had to accept some of the blame for the parlous decline in the Government's reputation. The department made significant forecasting errors over the changing magnitude of the deficit (repeatedly overestimating taxation 
receipts while underestimating the difficulties in re-balancing the books, or achieving 'fiscal consolidation'). Treasury also invited criticism over its wayward miscalculation of the amount of revenues the Mining Resource Rent Tax would generate, with the actual tax delivering only a couple of hundred million dollars by early 2013 and not the $\$ 3$ billion expected in the budget and nothing close to the $\$ 22.5$ billion over four years as originally expected. The Treasury Secretary, Martin Parkinson, blamed his department for not having sufficient data on the assumptions the mining companies were making in calculating their liabilities.

\section{Antagonising constituencies}

Arguably, the Labor Government made some major economic policy mistakes in its relations with business and households. It repeatedly announced proposals that concentrated the economic pain on powerful constituencies while spreading the benefits thinly. The Mining Super Profit Tax (then the Mining Resource Rent Tax) was guilty of this, as was the Carbon Tax initiative with a bureaucraticallydetermined high price for emissions passed directly on to household consumers. Other additional levies for floods, health care and disability care were targeted to middle and higher PAYE income earners out of budgetary necessity. The treasurer also seriously proposed increasing the tax on wealthy superannuants, but other senior ministers such as Simon Crean came out publicly and said the Government 'shouldn't be taxing people's [own] surpluses in order to fund our surpluses' (Kelly 2013). Universities were slugged with an overall efficiency dividend raising some $\$ 900$ million per annum to help offset the initial increased schools funding recommended by Gonski. Later under Rudd's second term as prime minister he announced his intention to remove the tax concessions on leased company cars, not understanding that many of these cars were used in the welfare and caring sectors and not anticipating that the proposals would cause severe disruptions in the car industry (producers and retailers) in its impact on new car orders.

Moreover, the Government continued to increase spending and to make significant long-term financial commitments, leading to an estimated escalation in the public debt burden to $\$ 220$ billion by $2015-16$. This was especially a problem with the Gillard Government (2010-13) which usually chose to spend forecasted funds it expected to receive long before it actually received them (and even then often did not receive the projected amount). This was true of both the carbon and mining taxes whose forecasted revenues were allocated before any tax was collected, and of the purported re-bounce in revenues over 2012-13. Long-term impositions on future budgets announced by Gillard as part of her intended legacy included: the increased school funding over seven years under the Gonski recommendations, the National Disability Insurance 
Scheme committing increased resources over eight years, as well as schemes to subsidise the wages of low paid workers especially in the carer and early childhood sectors.

The combined effect of these taxing-spending moves often alienated critics and did not appease intended beneficiaries. The mining industry waged an intense advertising war in 2010 with the Rudd Government before gaining concessions from Gillard that made the mining tax virtually ineffectual. Rural communities and small businesses strongly opposed the carbon tax, even though some would not be greatly affected and some would have gained from adaptation measures (afforestation).

\section{Arguments over Labor's economic management}

The net effect of the disappearing surplus and Labor's sequential broken promises to fix the budget meant that Labor's economic management record became an electoral liability for the Government, and an opportunity for the Coalition to really target its critique of the Government. Despite effectively combatting the GFC, the Government could not credibly campaign on its performance as an economic manager that had exercised sound fiscal management on public finances (see also AES data on Labor being markedly behind the Coalition as preferred managers of the economy by 22.8 per cent to 43.7 per cent-Bean et al. 2014: 86).

The Coalition had been a persistent critic of Labor's economic management since the end of 2008 when Malcolm Turnbull became opposition leader and had argued that the surplus measures were more generous than they needed to be and too costly to the budget. Under Abbott's leadership this criticism moved on to the general profligacy of Labor and inability to rebalance the budget. The shadow treasurer Joe Hockey in particular began to mount a neo-liberal case against 'big spending' and 'big government', promising to 'end the age of entitlement' (Hockey 2012).

Labor's problem in promoting its economic credentials was principally sheeted home to the treasurer Wayne Swan who was a poor communicator and salesman. His stewardship of the economy and particularly the budget came in for criticism from many quarters, and, given he had attached so strenuously his personal reputation to the goal of delivering a surplus, his credibility as an economic manager suffered accordingly. Unlike former treasurers Paul Keating or Peter Costello, but similar to Ralph Willis before him, Treasurer Swan was not a forceful advocate of the Government's economic credentials. He tended to overpromise and then under-deliver rather than the other way around. In speeches, interviews and press conferences he was often flat in his delivery, became 
tied up in technicalities, or shied away from boasting about his government's achievements. He once famously told an audience of serious journalist and financial writers assembled in the National Press Club after his 2011-12 budget that there was nothing to say about the budget other than that it had been difficult for him to put together and contained no good news. It may have been an honest remark but was not something his predecessors would have been likely to have admitted.

Rudd threw a further 'populist' spanner in the works when he implied that he favoured greater curbs on foreign ownership in Australia. In response to a constituent's question at the third leaders' debate (the people's forum at the Rooty Hill RSL Club) Rudd said he was concerned about the increasing levels of foreign ownership of Australian assets, and proposed to reduce the threshold at which proposed foreign acquisitions of land were vetted by the Foreign Investment Review Board (Abbott and Rudd 2013).

\section{The Coalition's proposals}

The Coalition did not promise explicitly to deliver a budgetary surplus; instead Abbott promised about a week out from election day that 'by the end of a Coalition Government's first term, the budget will be back on track to a believable surplus'. It was a calculated 'fudge' but enabled the Coalition to appear virtuous. He also said it might take until 2016-17 before a surplus could be achieved, promising that 'within a decade [by 2023] the budget surplus will be one per cent of GDP' (Berg 2013). These statements significantly watered down Joe Hockey's earlier commitment of January 2013 that he would return a surplus within one year of forming government. Hockey also changed his own tune during the campaign; and after his debate on economic policy with Treasurer Chris Bowen, where he said he would follow in the years ahead the same fiscal plans that Labor had announced, there was talk that the Coalition had belatedly opted for a 'unity ticket' on budgetary issues. Suddenly the structural deficit was not a point of policy difference, largely due to the realisation that there were significant difficulties with imposing major cuts on a fragile economy.

Beyond the issue of the deficit, the Coalition's plans for the economy were dotpoint slogans. The widely-circulated Our Plan document listed five economic objectives: two million new jobs over ten years; a 'five pillar economy' building on agriculture, mining and manufacturing industries; lower taxes; lower debt levels; and stronger national borders (Liberal Party of Australia 2013). 


\section{Squabbles over policy costings}

With all the advantages of incumbency and the public service on tap for expert advice, Labor claimed it had accurately costed all its policy changes - which were few and far between. It was less clear that the opposition had similarly managed to produce accurate costings. Previous oppositions had often come unstuck when their announced policy costings were shown by the Government to be flawed or new taxes were likely to hit harder than expected (for example, especially in the federal elections of 1987, 1993 and 1998). Hence oppositions had adopted the practice of delaying any detailed policy announcements until it was too late in the campaign for the Government or Treasury/Finance to produce contradictory costings. In this stand-off the Labor Government constantly challenged the opposition to 'come clean' on its policy commitments and release its own costings so they could be checked and verified or challenged. The Coalition steadfastly refused to comply with Labor's insistence until the end of the campaign, and when it eventually released its policies they were often capped and so the upper limits were declared fixed.

One policy that attracted much debate on the 'fairness' of the costs imposed on the community was the Coalition's paid parental leave scheme (PPL). Unlike Labor's 18-week scheme offered at the minimum wage, the Coalition promised a salary-based or workplace entitlement scheme that set the PPL according to the mother's wage up to a maximum of $\$ 75,000$ for six months. The Coalition costed this scheme at $\$ 5.5$ billion when fully operational, and proposed to pay for the policy through an additional temporary levy on big business but with savings offset from Labor's scheme. The ideological argument over this policy revolved around different interpretations of equity. Some Nationals argued that all women (including stay-at-home mums) should get the same benefit set at the level of the minimum wage. Other interests (including some unions and businesses) argued that mothers should have parental leave paid as a workplace entitlement (as many in the professions, the corporate sector and in public employment already enjoyed) with the rate dependent on the income of the employee (there was no provision for non-working mothers). The Greens supported the PPL but thought the Liberals' scheme too generous, and so proposed an income cap of $\$ 50,000$ over six months. Although the Coalition received much criticism for breaking the 'egalitarian statist spirit' based on minimal means-tested benefits, it persevered with its proposal in defiance of such criticisms. Some unionists and feminists viewing parental leave as an employment entitlement were less critical, as were those who favoured a contributory scheme that would make payments at variable rates. There was also a worry that many existing workplace schemes (in firms, universities, government departments) would transfer their entitlements over to the Coalition's proposed federal scheme which would likely add significantly to its overall costs. 


\section{Salience of economic and fiscal issues in the electorate}

Many commentators proclaimed in the campaign that 'economic management is by far the most important and influential issue for voters' (Keane 2013). And many thoughtful commentators attempted to urge serious debate on important topics for Australia's future or lamented the lack of meaningful engagement on issues. One former politician, Barry Jones, called it a terrible campaign, devoid of content, and 'the worst [he] could recall' (Jones 2013). This was by no means a novel criticism of recent political campaigns, as campaigns usually came down to strategies oriented towards winning, and were not necessarily about educating the public; indeed, any education of the electorate may have been an unintended consequence.

Yet issue polling demonstrated the economy remained a most pressing issue, and a top priority for many voters. In August, Newspoll found that health, the economy and education were 'very important issues' for voters (scoring respectively 75 per cent, 74 per cent and 73 per cent in importance), followed by 'cost of living' concerns on 65 per cent. The economy was considered best handled by the Coalition (by 49 per cent) compared to Labor (on 33 per cent) and support for the Coalition's economic management credentials continued to firm slightly over 2013. The Coalition was also regarded as likely to best handle cost of living pressures by 43 per cent to 35 per cent. An Age-Nielsen poll reported that 58 per cent of Australians considered the Coalition to be better economic managers compared to 38 per cent who thought Labor was the better manager. According to Colebatch (2013), this finding reflected a consistent pattern evidenced since the 1990-91 recession. However, Galaxy found that after the PPL was taken into account, some 43 per cent had confidence in the Coalition's stewardship of the economy, compared to 35 per cent who opted for Labor. Polls of marginal seats also put the economy and taxation as the main issues that 'would help most', with 40 per cent responding accordingly compared to 18 per cent who nominated welfare, and 8 per cent who opted for health (see Roy Morgan Research 2013).

In addition, a survey of 806 young voters in May 2013 listed jobs for young people entering the workforce ( 51 per cent) and the high cost of rent or housing generally (47 per cent) as the two most important issues that would affect their vote (Lucas 2013).

An ANUpoll survey released in August 2013 placed the economy/jobs as the most important problem facing Australia today (with 30.3 per cent of respondents indicating it as the top priority - twice the figure for immigration on 15.1 per cent and better government on 12.9 per cent, and well ahead of 
education (4.2 per cent) and health (3.6 per cent). Moreover, a further 21.2 per cent rated it as the second most important issue, meaning that 'just over half of the survey respondents mentioned the economy and jobs as a priority', a much higher percentage than had mentioned this issue in similar surveys in 2010 or 2011 (ANUpoll 2013). The AES survey also tended to confirm these trends (Bean et al. 2014: 86).

Given then the apparent salience of economic, employment and hip-pocket issues in the electorate, why were these issues latent in the campaign and not more prominent in the promotional strategies of the leaders and parties? Why didn't the economy resonate more noticeably? One factor may be that the media had an 'obsessive emphasis on personalities, stunts and trivia' and shied away from serious debate on issues, whether simple or complex (Jones 2013). Also the 'policy vacuum' may have tended to discourage debate about policy sectoral issues, although the PPL issue and the various elements of the comparable schemes were widely debated in an informed manner. It is also true that some fiscal and budgetary issues may have been hard to comprehend, overly complex and highly technical in nature, and when contradictory assertions or different versions of 'facts' were proffered electors tended to turn off. If complex financial issues appeared unclear and were not relevant to their personal circumstances then voters were likely to become sceptical, find the information tedious and to some extent become bored with issues. Alternatively, the perceptions of electors themselves may have been relevant. Voters may simply have believed that Labor had struggled with its fiscal policies and that the Coalition would do a better job at economic management - and so did not feel the need to get excited about economic issues. Or, perhaps sufficient numbers of voters had made up their minds about their voting intentions months ahead of the polls, and the campaign itself counted for little in terms of political communication or reshaping voting intentions.

\section{References}

Abbott, Tony. 2013. 'Address to the National Press Club'. Canberra, 2 September, viewed 15 April 2014: <www.liberal.org.au/latest-news/2013/09/02/tonyabbott-address-national-press-club-election-2013>.

Abbott, Tony and Rudd, Kevin. 2013. 'People's Forum'. Rooty Hill RSL Club, 28 August, viewed 14 October 2013: <www.kevinrudd.org.au/latest3_280813>.

ANUpoll. 2013. Attitudes to Electoral Reform. Ian McAllister, ANU College of Arts and Social Sciences, August, viewed 11 April 2014: < politicsir.cass.anu. edu.au/sites/default/files/ANUpoll-report-August-2014-attitudes-electoralreform.pdf $>$. 
Bean, Clive, McAllister, Ian, Pietsch, Juliet and Gibson, Rachel. 2014. Australian Election Study, 2013. Canberra: Australian Data Archive, The Australian National University.

Berg, Chris. 2013. “'On track" for a surplus? Not good enough'. The Drum, 3 September, viewed 11 April 2014: <www.abc.net.au/news/2013-09-03/bergon-track-for-a-surplus/4931502>.

Colebatch, Tim. 2013. 'Taking the prize, losing the plot'. Sydney Morning Herald, 4 September, viewed 9 October 2013: <www.smh.com.au/federalpolitics/federal-election-2013/taking-the-prize-losing-the-plot-20130903$2 \mathrm{t} 37 \mathrm{~m} . \mathrm{html}>$.

Harmon, Colm. 2013. 'Election 2013 Essays: It's the economy, stupid'. The Conversation, 4 September, viewed 11 April 2014: <theconversation.com/ election-2013-essays-its-the-economy-stupid-17470>.

Hockey, Joe. 2012. 'The End of the Age of Entitlement'. Address to the Institute of Economic Affairs, London, 17 April, viewed 11 April 2014: <www. joehockey.com/media-files/speeches/ContentPieces/100/download.pdf $>$.

Jones, Barry. 2013. 'Virtue and vexation: the policy vacuum in the 2013 election'. The Conversation, 16 September, viewed 11 April 2014: <theconversation. com/virtue-and-vexation-the-policy-vacuum-in-the-2013-election-18144>.

Keane, Bernard. 2013. 'Sound and fury signifying not much as both sides embrace unity tickets'. Crikey, 28 August, viewed 11 April 2014: <www. crikey.com.au/2013/08/30/sound-and-fury-signifying-not-much-as-bothsides-embrace-unity-tickets/?wpmp_switcher=mobile $>$.

Kelly, Joe. 2013. 'Simon Crean to fight plan for superannuation tax changes as internal rift deepens'. The Australian, 1 April, viewed 11 April 2014: $<$ www.theaustralian.com.au/national-affairs/policy/simon-crean-to-fightplan-for-superannuation-tax-changes-as-internal-rift-deepens/storyfn59nsif-1226610030006\#>.

Liberal Party of Australia. 2013. Real Solutions for all Australians. Canberra: Liberal Party of Australia. Available online from the website of the Liberal Party of Australia, viewed 18 March 2014: <lpa.webcontent.s3.amazonaws. com/realsolutions/LPA\%20Policy\%20Booklet\%20210x210_pages.pdf>.

Lucas, Clay. 2013. 'You are not listening, say young voters', Sydney Morning Herald, 7 August 2013, viewed 15 October 2014: <www.smh.com.au/ federal-politics/federal-election-2013/you-are-not-listening-say-youngvoters-20130806-2rdi7 html> 
Roy Morgan Research. 2013. 'The Economy, Tax and Welfare rank as top personal issues to electors in Corangamite and Corio'. 26 August, viewed 9 October 2013: <politicsir.cass.anu.edu.au/sites/default/files/ANUpollreport-August-2014-attitudes-electoral-reform.pdf $>$. 
This text taken from Abbott's Gambit: The 2013 Australian Federal Election, edited by Carol Johnson and John Wanna, published 2015 by ANU Press, The Australian National University, Canberra, Australia. 